\title{
Gaetbulibacter aestuarii sp. nov., isolated from shallow coastal seawater, and emended description of the genus Gaetbulibacter
}

\begin{abstract}
Correspondence
Chi Nam Seong

scnu@scnu.ac.kr
\end{abstract}

\author{
Seong Chan Park, ${ }^{1}$ Han Na Choe, ${ }^{1}$ Keun Sik Baik, ${ }^{1}$ Kang Hyun Lee ${ }^{2}$ \\ and Chi Nam Seong ${ }^{1}$
}

\author{
${ }^{1}$ Department of Biology, College of Life Science and Natural Resources, \\ Sunchon National University, Suncheon 540-742, Republic of Korea \\ ${ }^{2}$ Biological Resource Center, Korea Research Institute of Bioscience and Biotechnology, \\ 52 Oundong, Yuseong, Daejeon 305-333, Republic of Korea
}

\begin{abstract}
A rod-shaped, yellow and strictly aerobic marine bacterium, designated $\mathrm{KYW} 32^{\top}{ }^{\top}$, was isolated from seawater collected from the South Sea, Republic of Korea. Cells were Gram-negative and catalase- and oxidase-positive. The major fatty acids were iso- $C_{15: 1} G$, iso- $C_{15: 0}$, iso- $C_{17: 0}$ $3-\mathrm{OH}$, iso- $\mathrm{C}_{15: 0} 3-\mathrm{OH}$ and anteiso- $\mathrm{C}_{15: 0}$. The DNA G+C content was $32.4 \mathrm{~mol} \% \mathrm{~A}$ phylogenetic tree based on $16 \mathrm{~S}$ rRNA gene sequences showed that strain $\mathrm{KYW}_{3} 82^{\top}$ constituted an evolutionary lineage within the radiation enclosing the members of the genus Gaetbulibacter. The closest neighbour was Gaetbulibacter saemankumensis SMK-12 ${ }^{\top}$ (96.1\% 16S rRNA gene sequence similarity). A number of phenotypic characteristics distinguished strain $\mathrm{KYW} 382^{\top}$ from the described members of the genus Gaetbulibacter. On the basis of the data presented in this study, strain KYW382 ${ }^{\top}$ represents a novel species, for which the name Gaetbulibacter aestuarii sp. nov. is proposed. The type strain is $\mathrm{KYW}_{3} 82^{\top}\left(=\mathrm{KCTC} 23303^{\top}=\mathrm{JCM} 17455^{\top}\right)$. An emended description of the genus Gaetbulibacter is also given.
\end{abstract}

The genus Gaetbulibacter was described by Jung et al. (2005) as a new member of the family Flavobacteriaceae (Bernardet et al., 2002; Bernardet \& Nakagawa, 2006; Reichenbach, 1989) to accommodate Gram-negative, yellowpigmented, non-flagellated and rod-shaped cells devoid of flexirubin-type pigments (Yang \& Cho, 2008). At present, the genus Gaetbulibacter comprises two species with validly published names: Gaetbulibacter saemankumensis (Jung et al., 2005) isolated from tidal flat sediment and Gaetbulibacter marinus (Yang \& Cho, 2008) isolated from seawater.

During the course of a study on the microbial diversity of seawater, a yellow-pigmented bacterium, designated KYW $382^{\mathrm{T}}$, was isolated from seawater samples collected in the shallow coastal region of Gwangyang Bay $\left(34^{\circ} 54^{\prime} \mathrm{N}\right.$ $\left.128^{\circ} 43^{\prime} \mathrm{E}\right)$, South Sea, Republic of Korea. Isolation was achieved using the standard dilution-plating technique on marine agar (MA; Becton Dickinson) (Yang et al., 2006) and incubation at $25{ }^{\circ} \mathrm{C}$ for 7 days. Strain KYW $382^{\mathrm{T}}$ was routinely cultured on $\mathrm{MA}$ and preserved as a suspension in marine broth (MB; Becton Dickinson) containing $20 \%$ $(\mathrm{w} / \mathrm{v})$ glycerol at $-80{ }^{\circ} \mathrm{C}$.

The GenBank/EMBL/DDBJ accession number for the 16S rRNA gene sequence of strain $\mathrm{KYW}_{382}{ }^{\top}$ is GU552681.
Bacterial DNA preparation and PCR amplification and sequencing of the $16 \mathrm{~S}$ rRNA gene were carried out as described elsewhere (Chun \& Goodfellow, 1995). Identification of phylogenetic neighbours and calculation of pairwise sequence similarities were achieved using the EzTaxon server (http://www.eztaxon.org/; Chun et al., 2007). Sequences were aligned using CLUSTAL $x$ (Thompson et al., 1997) and the alignment was refined using PHYDIT version 3.1 (http://plaza.snu.ac.kr/ jchun/phydit/). Phylogenetic analysis was performed using PHYLIP (Felsenstein, 1993) and PAUP ${ }^{*} 4.0$ (Swofford, 1998). Phylogenetic trees were inferred using the maximum-parsimony (Fitch, 1971), neighbour-joining (Saitou \& Nei, 1987) and maximumlikelihood (Felsenstein, 1981) algorithms. The distance matrix for the neighbour-joining method was generated according to the model of Jukes \& Cantor (1969). The robustness of the topology of the neighbour-joining tree was evaluated by bootstrap analysis (Felsenstein, 1985) with 1000 resamplings.

An almost-complete 16S rRNA gene sequence (1458 nt) was obtained from strain KYW $382^{\mathrm{T}}$. Preliminary sequence comparison with $16 \mathrm{~S}$ rRNA gene sequences in GenBank indicated that the isolate was closely related to the genus Gaetbulibacter. The sequence from the isolate was then manually aligned with sequences from the genus Gaetbulibacter. Strain KYW382 ${ }^{\mathrm{T}}$ showed the highest $16 \mathrm{~S}$ 
rRNA gene sequence similarity with G. saemankumensis SMK-12 ${ }^{\mathrm{T}}(96.1 \%)$ followed by G. marinus IMCC $1914^{\mathrm{T}}$ $(95.7 \%)$. Sequence similarity with other members of the family Flavobacteriaceae was $<95.5 \%$. The neighbourjoining tree (Fig. 1) showed that strain KYW $382^{\mathrm{T}}$ formed a distinct lineage in the cluster comprising G. saemankumensis SMK $-12^{\mathrm{T}}$ and G. marinus IMCC $1914^{\mathrm{T}}$. The topology of the phylogenetic trees generated with the other algorithms was essentially the same (not shown). On the basis of $16 \mathrm{~S}$ rRNA gene sequence similarity and phylogenetic inference, it is clear that the isolate represents a novel genomic species within the genus Gaetbulibacter (Wayne et al., 1987). Because <97\% 16S rRNA gene sequence similarity is indicative of delineation at the species level (Stackebrandt \& Goebel, 1994), no DNA-DNA hybridization tests were needed to confirm the definition of a novel species.

Growth was tested on nutrient agar (NA), tryptic soy agar (TSA), R2A agar and glucose-yeast extract agar (GYEA; all from Becton Dickinson). Cell morphology and presence of flagella were examined by light microscopy and transmission electron microscopy (CM-20; Philips) with cells of exponentially growing cultures. Cells of strain $\mathrm{KYW}_{3} 82^{\mathrm{T}}$, G. saemankumensis KCTC $12379^{\mathrm{T}}$ and G. marinus KCCM $42380^{\mathrm{T}}$ grown on MA at $25{ }^{\circ} \mathrm{C}$ for 3 days were used for physiological and biochemical tests. Gliding motility was examined by observing cells grown in wet mounts with phase-contrast microscopy (DS-Fi1; Nikon). Growth at $4{ }^{\circ} \mathrm{C}, 10-50{ }^{\circ} \mathrm{C}$ (at $5{ }^{\circ} \mathrm{C}$ intervals), 37 and $42{ }^{\circ} \mathrm{C}$ was assessed in MB. Growth at pH 4.0-10.0 was assessed in MB with the $\mathrm{pH}$ adjusted using $100 \mathrm{mM}$ acetate buffer,
$100 \mathrm{mM} \mathrm{NaH}{ }_{2} \mathrm{PO}_{4} / \mathrm{Na}_{2} \mathrm{HPO}_{4}$ buffer or $100 \mathrm{mM} \mathrm{NaHCO} /$ $\mathrm{Na}_{2} \mathrm{CO}_{3}$ buffer (Yumoto et al., 2004). Growth with 0-10\% $\mathrm{NaCl}$ (in increments of $1 \% \mathrm{NaCl}$; Sigma) was determined in $\mathrm{NaCl}$-free artificial seawater medium (ASW) (per litre distilled water: $5.9 \mathrm{~g} \mathrm{MgCl}_{2} \cdot 6 \mathrm{H}_{2} \mathrm{O}, 3.24 \mathrm{~g} \mathrm{MgSO}_{4} \cdot 7 \mathrm{H}_{2} \mathrm{O}$, $1.8 \mathrm{~g} \mathrm{CaCl}_{2} .2 \mathrm{H}_{2} \mathrm{O}, 0.55 \mathrm{~g} \mathrm{KCl}, 0.16 \mathrm{~g} \mathrm{NaHCO}_{3}, 0.08 \mathrm{~g} \mathrm{KBr}$, $0.034 \mathrm{~g} \mathrm{SrCl}_{2} .6 \mathrm{H}_{2} \mathrm{O}, 0.022 \mathrm{~g} \mathrm{H}_{3} \mathrm{BO}_{3}, 0.008 \mathrm{~g} \mathrm{Na}_{2} \mathrm{H}_{2} \mathrm{PO}_{4}$, $0.004 \mathrm{~g} \mathrm{Na}_{2} \mathrm{SiO}_{3}, 0.0024 \mathrm{~g} \mathrm{NaF}$ and $0.0016 \mathrm{~g} \mathrm{NH}_{4} \mathrm{NO}_{3}$ ) supplemented with $5.0 \mathrm{~g}$ peptone and $1.0 \mathrm{~g}$ yeast extract (Yang \& Cho, 2008). Growth in an anaerobic chamber $\left(\mathrm{CO}_{2} / \mathrm{H}_{2} / \mathrm{N}_{2}\right.$, 10:10:80; Sheldon Manufacturing) was assessed on MA for 1 week. Acid production from glucose and maltose was tested as described by Yamaguchi \& Yokoe (2000). The presence of flexirubin-type pigments was determined by the bathochromatic shift test using $20 \%$ (w/v) KOH (Bernardet et al., 2002; McCammon \& Bowman, 2000). Catalase and oxidase activities were determined using $3 \%(\mathrm{v} / \mathrm{v})$ hydrogen peroxide and Kovács' reagent (Kovács, 1956), respectively. Nitrate reduction was tested in $\mathrm{MB}$ containing $0.2 \% \mathrm{KNO}_{3}$ (Skerman, 1967). $\mathrm{H}_{2} \mathrm{~S}$ production was determined on Kligler iron agar (Becton Dickinson) with $2 \%(\mathrm{w} / \mathrm{v}) \mathrm{NaCl}$. Degradation of the following macromolecules was tested on $\mathrm{MA}$ at $25{ }^{\circ} \mathrm{C}$ for 10 days (w/v; Sigma): casein (1\% skimmed milk), chitin (1\%), CMcellulose $(1 \%)$ and xylan (1\%). Degradation was revealed by the formation of clear zones around colonies either directly or after flooding with appropriate stains (Teather \& Wood, 1982). Hydrolysis of the following macromolecules was tested as described by Smibert \& Krieg (1994), on MA at $25{ }^{\circ} \mathrm{C}$ for 10 days (w/v; Sigma): egg yolk (10\%), starch $(0.2 \%)$, Tween $20(1 \%)$ and Tween $80(1 \%)$. Hydrolysis of L-tyrosine $(0.5 \%$, w/v; Sigma) was tested on MA (Barrow \&

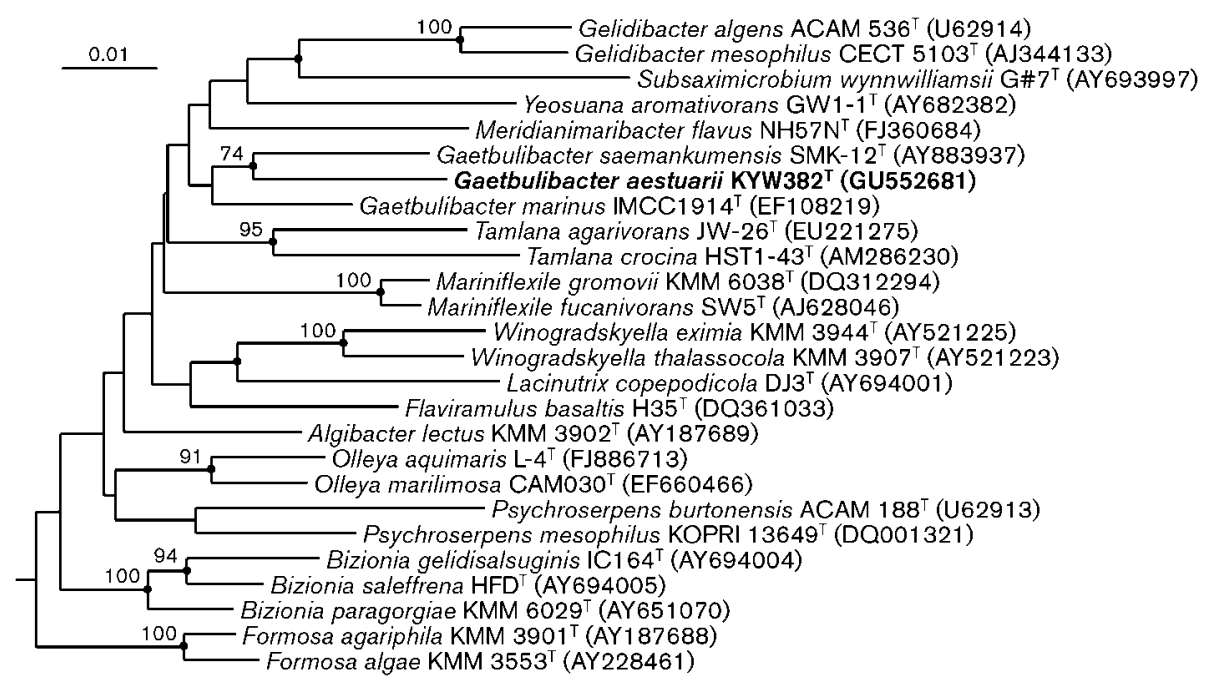

Fig. 1. Neighbour-joining tree based on $16 \mathrm{~S}$ rRNA gene sequences (1458 unambiguously aligned nucleotides) showing the phylogenetic position of strain $\mathrm{KYW} 382^{\top}$ and representatives of the family Flavobacteriaceae. Bootstrap values $(>70 \%)$ based on 1000 resamplings are shown at branch nodes. Filled circles indicate that the corresponding nodes were also recovered in trees generated with the maximum-parsimony and maximum-likelihood algorithms. Bar, 0.01 substitutions per nucleotide position. 
Feltham, 1993). DNase activity was determined on DNase test agar (Becton Dickinson) supplemented with $2 \%$ (w/ v) $\mathrm{NaCl}$. Other biochemical tests and enzyme activity tests were performed using API $20 \mathrm{NE}$ and API ZYM strips (bioMérieux) and the GN2 MicroPlate kit (Biolog) according to the manufacturers' instructions except that cells were suspended in distilled water supplemented with $2 \%(\mathrm{w} / \mathrm{v}) \mathrm{NaCl}$. Antibiotic resistance was determined by the disc-diffusion method using commercial antibioticimpregnated discs (BBL Becton Dickinson). After 7 days of incubation at $25{ }^{\circ} \mathrm{C}$ on $\mathrm{MA}$, the results were interpreted according to the guidelines set forth by the CLSI (2003).

Cells of strain KYW $382^{\mathrm{T}}$ were strictly aerobic, Gramnegative, non-motile rods. Detailed results of the physiological and biochemical analyses are given in Table 1 and the species description. Several phenotypic characteristics readily distinguished strain $\mathrm{KYW} 382^{\mathrm{T}}$ from its closest phylogenetic relatives.

For cellular fatty acid analysis, strain $\mathrm{KYW}_{382^{\mathrm{T}}}, G$. saemankumensis KCTC $12379^{\mathrm{T}}$ and G. marinus KCCM $42380^{\mathrm{T}}$ were grown on MA for 3 days at $25^{\circ} \mathrm{C}$. The fatty acid methyl esters were analysed by GLC and a MIDI aerobe method (Chem Station, version 4.02) according to the instructions of the Microbial Identification System (MIDI, 1999). For G $+\mathrm{C}$ content analysis, DNA of strain KYW $382^{\mathrm{T}}$ was prepared in duplicate and analysed by the thermal denaturation method of Marmur \& Doty (1962). The fatty acid profile of strain KYW $382^{\mathrm{T}}$ was essentially similar to those of the two Gaetbulibacter type strains, although the proportions of iso- $\mathrm{C}_{15: 1} \mathrm{G}$, iso- $\mathrm{C}_{15: 0}$ and summed feature $3\left(\mathrm{C}_{16: 1} \omega 7 \mathrm{c}\right.$ and/or iso- $\left.\mathrm{C}_{15: 0} 2-\mathrm{OH}\right)$ were lower in G. saemankumensis KCTC $12379^{\mathrm{T}}$ (Table 2). The DNA G + C content of strain KYW $382^{\mathrm{T}}$ was $32.4 \pm$ $0.4 \mathrm{~mol} \%$, a value lower than those reported for the reference strains (Table 1).

The phylogenetic, phenotypic and chemotaxonomic data clearly indicate that strain KYW $382^{\mathrm{T}}$ represents a novel species within the genus Gaetbulibacter, for which the name Gaetbulibacter aestuarii sp. nov. is proposed. The description of the genus Gaetbulibacter is also emended.

\section{Emended description of the genus Gaetbulibacter Jung et al. 2005 emend. Yang and Cho 2008}

The description of the genus is as given by Jung et al. (2005) and emended by Yang \& Cho (2008) with the following modification. The DNA G+C content is $32.4-$ $38.1 \mathrm{~mol} \%$.

\section{Description of Gaetbulibacter aestuarii sp. nov.}

Gaetbulibacter aestuarii (aes.tu.a'ri.i. L. gen. n. aestuarii of the shallow coast, from where the type strain was isolated).
Table 1. Differential characteristics of strain $\mathrm{KYW} 382^{\top}$ and the type strains of species of the genus Gaetbulibacter

Strains: 1, Gaetbulibacter aestuarii sp. nov. KYW $382^{\mathrm{T}} ; 2$, G. marinus KCCM $42380^{\mathrm{T}}$; 3, G. saemankumensis KCTC $12379^{\mathrm{T}}$. All data were obtained in this study unless indicated otherwise. All strains were positive for hydrolysis of aesculin and L-tyrosine and activities of acid phosphatase, alkaline phosphatase, catalase, leucine arylamidase and valine arylamidase. All strains were negative for flexirubin-type pigments, indole production, hydrolysis of casein, chitin, CMcellulose, DNA, Tween 80, urea and xylan and activities of cystine arylamidase, esterase (C4), esterase lipase (C8), $\alpha$-fucosidase, $\alpha$ galactosidase, $\beta$-glucuronidase, lipase (C14), $\alpha$-mannosidase and trypsin.

\begin{tabular}{|lccc|}
\hline Characteristic & $\mathbf{1}$ & $\mathbf{2}$ & $\mathbf{3}$ \\
\hline Facultatively anaerobic & - & - & + \\
Reduction of nitrate & - & - & + \\
Acidification of glucose & - & $+^{*}$ & + \\
Gliding motility & - & - & + \\
Oxidase activity & + & - & + \\
Hydrolysis of: & & & \\
$\quad$ Gelatin & + & - & $+^{*}$ \\
Starch & + & - & + \\
Tween 20 & + & - & + \\
Enzyme activity (API ZYM) & & & \\
$\quad N$-Acetyl- $\beta$-glucosaminidase & + & - & + \\
$\alpha$-Chymotrypsin & + & $-{ }^{*}$ & - \\
$\beta$-Galactosidase & + & - & - \\
$\alpha$-Glucosidase & - & $+^{*}$ & + \\
$\beta$-Glucosidase & + & $-\star$ & - \\
$\quad$ Naphthol-AS-BI-phosphohydrolase & - & + & - \\
DNA G+C content (mol\%) & 32.4 & $38.1 \dagger$ & $34.8 \dagger$ \\
\hline
\end{tabular}

${ }^{\star}$ Results differ from those reported by Yang \& Cho (2008) and Jung et al. (2005).

$\dagger$ Data from Yang \& Cho (2008) and Jung et al. (2005).

Cells are Gram-negative, strictly aerobic, non-motile, slender rods $(0.3 \mu \mathrm{m}$ wide and $1.5-4.0 \mu \mathrm{m}$ long $)$. Colonies on MA are circular with entire margins, convex, smooth, opaque, yellow and approximately $1.0-2.0 \mathrm{~mm}$ in diameter after 3 days at $30{ }^{\circ} \mathrm{C}(\mathrm{pH} 7)$. Growth occurs on MA, but not on GYEA, NA, R2A agar or TSA. Growth occurs with $1-9 \%(\mathrm{w} / \mathrm{v}) \mathrm{NaCl}$ (optimum $2-3 \%$ ), at $\mathrm{pH}$ 5-8 (optimum $\mathrm{pH} 7$ ) and at $10-40{ }^{\circ} \mathrm{C}$ (optimum $25-$ $35{ }^{\circ} \mathrm{C}$ ). Oxidase- and catalase-positive. Flexirubin-type pigments are absent ( $\mathrm{KOH}$ test-negative). Negative for $\mathrm{H}_{2} \mathrm{~S}$ and indole production, nitrate reduction and acid production from D-glucose and maltose. Aesculin, gelatin, starch, Tween 20 and L-tyrosine are hydrolysed, but CMcellulose, casein, chitin, DNA, egg yolk, Tween 80 and xylan are not. With API ZYM, $N$-acetyl- $\beta$-glucosaminidase, acid phosphatase, alkaline phosphatase, $\alpha$-chymotrypsin, $\beta$ galactosidase, $\beta$-glucosidase, leucine arylamidase and valine arylamidase are present, but cystine arylamidase, esterase (C4), esterase lipase (C8), $\alpha$-fucosidase, $\alpha$-galactosidase, 
Table 2. Fatty acid compositions of strain $\mathrm{KYW} 382^{\top}$ and the type strains of species of the genus Gaetbulibacter

Strains: 1, G. aestuarii sp. nov. KYW $382^{\mathrm{T}}$; 2, G. marinus KCCM $42380^{\mathrm{T}}$; 3, G. saemankumensis KCTC $12379^{\mathrm{T}}$. Data were obtained in this study using cells grown on MA at $25{ }^{\circ} \mathrm{C}$ for 3 days. Values are percentages of total fatty acids; fatty acids amounting to $<1 \%$ of the total in all strains are not shown. ECL, Equivalent chain-length; tr, trace $(<1 \%)$; - , not detected.

\begin{tabular}{|c|c|c|c|}
\hline Fatty acid & 1 & 2 & 3 \\
\hline \multicolumn{4}{|l|}{ Straight-chain } \\
\hline $\mathrm{C}_{15: 0}$ & 2.0 & 3.1 & 1.8 \\
\hline$C_{16: 0}$ & 2.2 & 1.3 & 2.3 \\
\hline $\mathrm{C}_{18: 0}$ & 1.7 & $\operatorname{tr}$ & 1.1 \\
\hline \multicolumn{4}{|l|}{ Branched } \\
\hline anteiso- $\mathrm{C}_{15: 0}$ & 6.0 & 3.6 & 7.9 \\
\hline anteiso- $\mathrm{C}_{15: 1} \mathrm{~A}$ & 1.8 & 1.8 & 1.5 \\
\hline anteiso- $\mathrm{C}_{17: 1} \omega 9 c$ & - & - & 1.2 \\
\hline iso- $\mathrm{C}_{13: 0}$ & 1.2 & $\operatorname{tr}$ & 1.6 \\
\hline iso- $\mathrm{C}_{14: 0}$ & $\operatorname{tr}$ & 1.2 & $\operatorname{tr}$ \\
\hline iso- $\mathrm{C}_{15: 0}$ & 21.5 & 22.2 & 15.3 \\
\hline iso- $\mathrm{C}_{16: 0}$ & $\operatorname{tr}$ & 1.6 & $\operatorname{tr}$ \\
\hline iso- $\mathrm{C}_{15: 1} \mathrm{G}$ & 23.0 & 26.8 & 8.0 \\
\hline iso- $\mathrm{C}_{17: 1} \omega 9 c$ & $\operatorname{tr}$ & $\operatorname{tr}$ & 1.5 \\
\hline \multicolumn{4}{|l|}{ Hydroxy } \\
\hline $\mathrm{C}_{15: 0} 2-\mathrm{OH}$ & $\operatorname{tr}$ & $\operatorname{tr}$ & 1.8 \\
\hline $\mathrm{C}_{17: 0} 2-\mathrm{OH}$ & 1.8 & 1.2 & 4.1 \\
\hline $\mathrm{C}_{16: 0} 3-\mathrm{OH}$ & $\operatorname{tr}$ & $\operatorname{tr}$ & 1.2 \\
\hline iso- $\mathrm{C}_{16: 0} 3-\mathrm{OH}$ & 4.8 & 7.7 & 3.6 \\
\hline iso- $\mathrm{C}_{17: 0} 3-\mathrm{OH}$ & 12.7 & 11.2 & 19.6 \\
\hline iso- $\mathrm{C}_{15: 0} 3-\mathrm{OH}$ & 6.8 & 6.5 & 6.9 \\
\hline \multicolumn{4}{|l|}{ Unknown } \\
\hline ECL 13.565 & 3.0 & 1.8 & 2.4 \\
\hline ECL 16.582 & $\operatorname{tr}$ & $\operatorname{tr}$ & 1.0 \\
\hline Summed feature $3^{*}$ & 3.0 & 2.9 & 11.3 \\
\hline
\end{tabular}

*Summed features represent groups of two or three fatty acids that cannot be separated by the Microbial Identification System. Summed feature 3 consisted of $\mathrm{C}_{16: 1} \omega 7 c$ and/or iso- $\mathrm{C}_{15: 0} 2-\mathrm{OH}$.

$\alpha$-glucosidase, $\beta$-glucuronidase, lipase (C14), $\alpha$-mannosidase, naphthol-AS-BI-phosphohydrolase and trypsin activities are absent. With the Biolog GN2 MicroPlate, acetic acid, L-asparagine, L-aspartic acid, cellobiose, dextrin, Dfructose, D-galactose, gentiobiose, $\alpha$-D-glucose, $\alpha$-D-glucose 1-phosphate, glucose 6-phosphate, glutamic acid, glycyl L-aspartic acid, glycyl L-glutamic acid, hydroxy-L-proline, lactose, lactulose, maltose, $\mathrm{D}$-mannose, melibiose, methyl $\beta$ D-glucoside, L-ornithine, L-proline, raffinose, L-rhamnose, sucrose, trehalose, turanose and L-threonine are utilized; all other substrates are not utilized. Sensitive to ( $\mu \mathrm{g}$ per disc, unless otherwise indicated): ampicillin (10), chloramphenicol (30), erythromycin (15) and penicillin (10 IU), but resistant to amikacin (30), gentamicin (10), kanamycin (30), nalidixic acid (30), polymyxin B (300 IU), streptomycin (10), tetracycline (30) and vancomycin (30). The major fatty acids $\left(>5 \%\right.$ of the total) are iso- $\mathrm{C}_{15: 1} \mathrm{G}$, iso- $\mathrm{C}_{15: 0}$, iso- $\mathrm{C}_{17: 0} 3-\mathrm{OH}$, iso- $\mathrm{C}_{15: 0} 3-\mathrm{OH}$ and anteiso- $\mathrm{C}_{15: 0}$. The DNA $\mathrm{G}+\mathrm{C}$ content of the type strain is $32.4 \mathrm{~mol} \%$.

The type strain is KYW $382^{\mathrm{T}}\left(=\mathrm{KCTC} 23303^{\mathrm{T}}=\mathrm{JCM} 17455^{\mathrm{T}}\right)$, isolated from seawater collected from the South Sea, Republic of Korea.

\section{Acknowledgements}

This research was supported by the 21C Frontier Microbial Genomics and Applications Center Program, Ministry of Education, Science \& Technology, Republic of Korea.

\section{References}

Barrow, G. I. \& Feltham, R. K. A. (editors) (1993). Cowan and Steel's Manual for the Identification of Medical Bacteria, 3rd edn. Cambridge: Cambridge University Press.

Bernardet, J.-F. \& Nakagawa, Y. (2006). An introduction to the family Flavobacteriaceae. In The Prokaryotes, a Handbook on the Biology of Bacteria, 3rd edn, vol. 7, pp. 455-480. Edited by M. Dworkin, S. Falkow, E. Rosenberg, K. H. Schleifer \& E. Stackebrandt. New York: Springer.

Bernardet, J. F., Nakagawa, Y. \& Holmes, B. (2002). Proposed minimal standards for describing new taxa of the family Flavobacteriaceae and emended description of the family. Int J Syst Evol Microbiol 52, 1049-1070.

Chun, J. \& Goodfellow, M. (1995). A phylogenetic analysis of the genus Nocardia with $16 \mathrm{~S}$ rRNA gene sequences. Int J Syst Bacteriol 45, 240-245.

Chun, J., Lee, J.-H., Jung, Y., Kim, M., Kim, S., Kim, B. K. \& Lim, Y.-W. (2007). EzTaxon: a web-based tool for the identification of prokaryotes based on $16 \mathrm{~S}$ ribosomal RNA gene sequences. Int J Syst Evol Microbiol 57, 2259-2261.

CLSI (2003). Performance standards for antimicrobial disk susceptibility tests, 8th edn. Wayne, PA: Clinical and Laboratory Standards Institute.

Felsenstein, J. (1981). Evolutionary trees from DNA sequences: a maximum likelihood approach. J Mol Evol 17, 368-376.

Felsenstein, J. (1985). Confidence limits on phylogenies: an approach using the bootstrap. Evolution 39, 783-791.

Felsenstein, J. (1993). PHYLIP (phylogeny inference package) version 3.5c. Distributed by the author. Department of Genome Sciences, University of Washington, Seattle, USA.

Fitch, W. M. (1971). Toward defining the course of evolution: minimum change for a specific tree topology. Syst Zool 20, 406-416.

Jukes, T. H. \& Cantor, C. R. (1969). Evolution of protein molecules. In Mammalian Protein Metabolism, vol. 3, pp. 21-132. Edited by H. N. Munro. New York: Academic Press.

Jung, S.-Y., Kang, S.-J., Lee, M.-H., Lee, S.-Y., Oh, T.-K. \& Yoon, J.-H. (2005). Gaetbulibacter saemankumensis gen. nov., sp. nov., a novel member of the family Flavobacteriaceae isolated from a tidal flat sediment in Korea. Int J Syst Evol Microbiol 55, 1845-1849.

Kovács, N. (1956). Identification of Pseudomonas pyocyanea by the oxidase reaction. Nature 178, 703.

Marmur, J. \& Doty, P. (1962). Determination of the base composition of deoxyribonucleic acid from its thermal denaturation temperature. J Mol Biol 5, 109-118.

McCammon, S. A. \& Bowman, J. P. (2000). Taxonomy of Antarctic Flavobacterium species: description of Flavobacterium gillisiae sp. 
nov., Flavobacterium tegetincola sp. nov., and Flavobacterium xanthum sp. nov., nom. rev. and reclassification of [Flavobacterium] salegens as Salegentibacter salegens gen. nov., comb. nov. Int J Syst Evol Microbiol 50, 1055-1063.

MIDI (1999). Sherlock Microbial Identification System Operating Manual, version 3.0. Newark, DE: MIDI, Inc.

Reichenbach, H. (1989). The order Cytophagales Leadbetter 1974, $99^{\mathrm{AL}}$. In Bergey's Manual of Systematic Bacteriology, vol. 3, pp. 20112013. Edited by J. T. Staley, M. P. Bryant, N. Pfennig \& J. G. Holt. Baltimore: Williams \& Wilkins.

Saitou, N. \& Nei, M. (1987). The neighbor-joining method: a new method for reconstructing phylogenetic trees. Mol Biol Evol 4, 406-425.

Skerman, V. B. D. (1967). A Guide to the Identification of the Genera of Bacteria, 2nd edn. Baltimore: Williams \& Wilkins.

Smibert, R. M. \& Krieg, N. R. (1994). General characterization. In Methods for General and Molecular Bacteriology, pp. 607-654. Edited by P. Gerhardt, R. G. E. Murray, W. A. Wood \& N. R. Krieg. Washington, DC: American Society for Microbiology.

Stackebrandt, E. \& Goebel, B. M. (1994). Taxonomic note: a place for DNA-DNA reassociation and 16S rRNA sequence analysis in the present species definition in bacteriology. Int J Syst Bacteriol 44, 846849.

Swofford, D. L. (1998). Phylogenetic analysis using parsimony (PAUP), version 4. Sunderland, MA: Sinauer Associates.

Teather, R. M. \& Wood, P. J. (1982). Use of Congo red-polysaccharide interactions in enumeration and characterization of cellulolytic bacteria from the bovine rumen. Appl Environ Microbiol 43, 777780 .

Thompson, J. D., Gibson, T. J., Plewniak, F., Jeanmougin, F. \& Higgins, D. G. (1997). The CLUSTAL_X windows interface: flexible strategies for multiple sequence alignment aided by quality analysis tools. Nucleic Acids Res 25, 4876-4882.

Wayne, L. G., Brenner, D. J., Colwell, R. R., Grimont, P. A. D., Kandler, O., Krichevsky, M. I., Moore, L. H., Moore, W. E. C., Murray, R. G. E. \& other authors (1987). International Committee on Systematic Bacteriology. Report of the ad hoc committee on reconciliation of approaches to bacterial systematics. Int J Syst Bacteriol 37, 463-464.

Yamaguchi, S. \& Yokoe, M. (2000). A novel protein-deamidating enzyme from Chryseobacterium proteolyticum sp. nov., a newly isolated bacterium from soil. Appl Environ Microbiol 66, 33373343.

Yang, S.-J. \& Cho, J.-C. (2008). Gaetbulibacter marinus sp. nov., isolated from coastal seawater, and emended description of the genus Gaetbulibacter. Int J Syst Evol Microbiol 58, 315-318.

Yang, S.-H., Kwon, K. K., Lee, H.-S. \& Kim, S.-J. (2006). Shewanella spongiae sp. nov., isolated from a marine sponge. Int J Syst Evol Microbiol 56, 2879-2882.

Yumoto, I., Hirota, K., Yamaga, S., Nodasaka, Y., Kawasaki, T., Matsuyama, H. \& Nakajima, K. (2004). Bacillus asahii sp. nov., a novel bacterium isolated from soil with the ability to deodorize the bad smell generated from short-chain fatty acids. Int J Syst Evol Microbiol 54, 1997-2001. 